\title{
PENGARUH APLIKASI PUPUK HAYATI TERHADAP DINAMIKA KELIMPAHAN MIKROB PADA LAHAN BEKAS TAMBANG TIMAH YANG DITANAMI TANAMAN LADA (Piper nigrum L.)
}

\author{
Biofertilizer Application Influence in Dinamics of Microorganisms \\ Abundance on Tin Mined Area planted Pepper Plant (Piper nigrum L.)
}

\author{
Patimah Siti*, Inonu Ismed dan Asriani Euis \\ Program Studi Agoteknologi, FPPB, Universitas Bangka Belitung, Balunijuk, Kabupaten Bangka, \\ Kepulauan Bangka Belitung
}

\begin{abstract}
Biofertilizer is a fertilizer containing nine microbial consortia that useful for plant growth. The benefits of using biofertilizers are to improve fertilizer efficiency, maintain fertility soil and plant health, improving yield and sustainability. The aim of this research was to know the effect of the biofertilizer dosage to the population dynamics of microbial abundance of tin mined area planted with pepper plant (Piper nigrum L.). The method used is a direct observation method in the field through soil sampling with a purposive sampling technique. Six Soil samples were taken from every level of treatment. Soil samples were isolated, PDA media for fungi, NA media for bacteria and pikovskaya media for microbes solubilazition phosphate testing for both bacteria and fungi consisting of 54 plates. Result of the research indicate that different dosage of biofertilizers did not affect the dynamics of micro-organisms abundance. Treatment of $B 4\left(10 \mathrm{~g} \mathrm{~L}^{-1}\right.$ plant $\left.{ }^{-1}\right)$ gave a good effect on the abundance of fungi. While the treatment of $B 3\left(5 \mathrm{~g} \mathrm{~L}^{-1}\right.$ plant $\left.^{-1}\right)$ gave a good effect on bacterial abundance. The result of nitrogen-fixing test was obtained by $N$ inhibiting bacteria on NFB media in the presence of a pellicle at the bottom of the test tube. The result of the phosphate solubilization test was obtained with clear zones surrounded bacteria and fungi. Analyzed six soil samples contained nitrogen-fixing bacteria and Bacillus cereus with bacteria as phosphate solubilization bacteria.
\end{abstract}

Keywords: Dosage, microbial phosphate solubilization, nitrogen-fixing microorganism

\section{ABSTRAK}

Pupuk hayati (biofertilizer) merupakan pupuk yang mengandung 9 konsorsium mikrob dan bermanfaat untuk pertumbuhan tanaman. Keuntungan penggunaan pupuk hayati adalah untuk meningkatkan efisiensi pemupukan, menjaga kesuburan serta kesehatan tanah dan tanaman, sehingga meningkatkan hasil dan berkelanjutan. Penelitian ini bertujuan untuk mengetahui pengaruh dosis pupuk hayati terhadap dinamika kelimpahan mikrob tanah di lahan bekas tambang timah yang ditanami tanaman lada (Piper nigrum L.) Metode yang digunakan adalah observasi langsung di lapangan melalui pengambilan sampel tanah dengan teknik purposive sampling. Sampel tanah diambil dari setiap taraf perlakuan pada lahan bekas tambang timah yang ditanami tanaman lada sebanyak 6 sampel. Seluruh sampel tanah kemudian diisolasi, media PDA untuk cendawan, media NA untuk bakteri dan media pikovskaya untuk pengujian mikrob pelarut fosfat baik untuk bakteri maupun cendawan, sehingga diperoleh sebanyak 54 cawan. Hasil menunjukkan bahPemberian dosis pupuk hayati yang berbeda-beda tidak berpengaruh terhadap dinamika kelimpahan mikrob. Perlakuan B4 $\left(10 \mathrm{~g} \mathrm{~L}^{-1} \operatorname{tanaman}^{-1}\right)$ memberikan pengaruh yang relatif baik terhadap kelimpahan cendawan. Sedangkan perlakuan B3 $\left(5 \mathrm{~g} \mathrm{~L}^{-1}\right.$ tanaman $\left.^{-1}\right)$ memberikan pengaruh yang relatif baik terhadap kelimpahan bakteri. Hasil dari uji fiksasi nitrogen diperoleh bakteri penambat $\mathrm{N}$ pada media NFB dengan adanya pellicle pada bagian bawah tabung reaksi. Hasil uji pelarut fosfat diperoleh dengan zona bening yang mengelilingi bakteri dan cendawan. Dari 6 sampel tanah yang dianalisis mengandung bakteri fiksasi nitrogen dan Bacillus cereus dengan bakteri sebagai pelarut fosfat.

Kata kunci: Dosis, mikrob pelarut fosfat, mikrob penambat nitrogen

\section{PENDAHULUAN}

Ketersediaan mikrob di dalam tanah saat ini semakin sedikit akibat penggunaan pestisida dan herbisida berlebihan dalam pertanian. Menurut Nunik et al. (2011) dampak pemberian pestisida pada tanaman dapat mempengaruhi populasi mikrob di dalam tanah. Upaya mengurangi pencemaran lingkungan dan pemanasan global di lahan pertanian yang disebabkan oleh penggunaan pupuk kimia yang berlebihan, maka perlu dicari alternatif penggunaan pupuk yang ramah lingkungan (Sudrajat et al., 2014).
Beberapa teknologi tepat guna untuk mereduksi penggunaan pupuk anorganik sudah banyak dilakukan oleh petani, salah satunya adalah penggunaan pupuk hayati. Beberapa jenis pupuk hayati yang sering digunakan seperti bakteri penambat nitrogen, bakteri pelarut fosfat, bakteri perombak kitin (kitinolitik), bakteri perombak selulosa (selulolitik), dan beberapa jenis pupuk hayati lain yang mencapai 35 jenis menurut data yang terdaftar pada Direktorat Pupuk dan Pestisida (Simangunkalit et al., 2006). Semua jenis pupuk hayati berfungsi untuk mereduksi penggunaan pupuk anorganik untuk satu atau beberapa unsur hara yang terkandung tanpa mengurangi hasil panen tanaman, menyuburkan dan memperbaiki struktur tanah, 
serta membantu tanaman dalam penanggulangan penyakit tanah (Gentili dan Jumpponen, 2005).

Pupuk hayati (biofertilizer) merupakan pupuk yang mengandung 9 konsorsium mikrob dan bermanfaat untuk pertumbuhan tanaman (Vessey, 2003). Kelompok mikrob yang sering digunakan dalam pupuk hayati adalah kelompok mikrob yang mampu menyediakan unsur makro bagi tanaman yaitu unsur N, P, dan K (Nasahi, 2010). Mikrob-mikrob tersebut adalah mikrob penambat $\mathrm{N}$ dari udara serta mikrob pelarut hara $\mathrm{P}$ dan $\mathrm{K}$ dalam tanah. Kelompok mikrob tersebut adalah Rhizobium sp., Azospirilium sp., dan Azotobacter sp., yang berfungsi untuk memfiksasi nitrogen, Aspergilus sp., Pseudomonas sp., (Adesemoye et al., 2008) dan Lactobacillus sp. berfungsi untuk melarutkan fosfat dan kalium (Sofatin, 2016). Keuntungan penggunaan pupuk hayati adalah untuk meningkatkan efisiensi pemupukan, menjaga kesuburan serta kesehatan tanah dan tanaman, sehingga meningkatkan hasil dan berkelanjutan (Saraswati, 2012).

Populasi mikrob tanah yang terdiri atas alga biruhijau, fitoplankton, bakteri, cendawan, dan aktinomiset pada permukaan dan lapisan olah tanah mencapai puluhan juta setiap gram tanah, yang merupakan bagian integral dan pembentuk kesuburan tanah pertanian (Mc Mahon et al., 2011; Prajnanta, 2004). Proses daur ulang secara alamiah di permukaan dan lapisan olah tanah yang sangat penting bagi kegiatan pertanian tidak terjadi tanpa aktivitas mikrob (Iqbal et al, 2011). Manfaat mikrob dalam usaha pertanian belum disadari sepenuhnya, bahkan sering diposisikan sebagai komponen habitat yang merugikan, karena pandangan umum terhadap mikrob lebih terfokus secara selektif pada mikrob patogen yang menimbulkan penyakit pada tanaman (Saraswati dan Sumarno, 2008). Spesies mikrob sebagian besar merupakan mikroflora yang bermanfaat, kecuali beberapa jenis spesifik yang dapat menyebabkan penyakit bagi tanaman (Watanabe, 1978).

Tanah dianggap sebagai gudang aktifitas mikrob. Aktifitas mikrob terbatas yaitu pada agregat dengan akumulasi bahan organik, rhizosfer. Komunitas mikrob tanah seringkali sulit untuk dikarakterisasi, terutama karena fenotipnya yang luar biasa keragaman genotip dan heterogenitas. Populasi bakteri dilapisan atas profil tanah dapat menghasilkan lebih dari $10^{9} \mathrm{sel} \mathrm{g}^{-1}$ tanah.

Penerapan pupuk organik hayati perlu dilakukan dengan cermat (Suwahyono, 2011). Hal ini dikarenakan kandungan mikrob di dalamnya merupakan kumpulan makhluk hidup yang berukuran mikroskopis, sehingga perlu dijaga agar tetap hidup dan mampu berkembang biak pada areal lahan. Proses perkembangbiakan mikrob juga membutuhkan waktu untuk mencapai populasi yang optimum (Fadiluddin, 2009).

Berdasarkan uraian di atas, penelitian yang sudah dilakukan Rifal mengenai pemberian bahan pembenah tanah pada lahan bekas tambang timah untuk pertumbuhan awal tanaman lada dengan hasil penelitian bahwa pemberian bahan pembenah tanah berpengaruh nyata. Kombinasi bahan pembenah tanah pupuk $\mathrm{NPK}+$ mikoriza+pupuk hayati merupakan perlakuan terbaik untuk pertumbuhan tanaman lada dilahan tailing pasca penambangan timah (Sujitno, 2007).

Tujuan dari penelitian ini adalah: (i) Mengetahui pengaruh dosis pupuk hayati terhadap dinamika kelimpahan mikrob tanah di lahan bekas tambang timah yang ditanami tanaman lada (P. nigrum L.), (ii) Mengetahui berapa dosis terbaik pemberian pupuk hayati terhadap pertumbuhan optimal mikrob di lahan bekas tambang timah yang ditanami tanaman lada (P. nigrum L.).

Hipotesis penelitian ini adalah: (i) Pemberian dosis pupuk hayati memberikan pengaruh terhadap dinamika kelimpahan mikrob tanah di lahan bekas tambang timah yang ditanami tanaman lada, (ii) Dosis pupuk hayati $10 \mathrm{~g}$ liter $^{-1}$ tanaman $^{-1}$ memberikan dinamika kelimpahan mikrob terbaik untuk di lahan bekas tambang timah yang ditanami tanaman lada.

\section{BAHAN DAN METODA}

\section{Bahan dan Alat}

Bahan-bahan yang digunakan dalam pelaksanaan penelitian ini adalah alkohol 70\%, media JNFb, media NFb, media PDA, media pikovskaya, media NA, media WA, media Azospirilum, media LG, spiritus, tanah dan tissue. Sedangkan alat-alat yang digunakan dalam pelaksanaan penelitian ini adalah alat tulis, autoklaf, bor tanah, bunsen, cawan petri, erlenmeyer, gelas beker, gunting, jarum ose, kamera, laminar airflow, laptop, nampan, $\mathrm{pH}$ tester, plastik, pipet tetes, Soil Moisture Meter, spayer, tabung reaksi dan timbangan digital.

\section{Metode Penelitian}

Metode yang digunakan dalam penelitian ini yaitu metode observasi langsung di lapangan melalui pengambilan sampel tanah. Teknik pengambilan sampel yang digunakan adalah teknik purposive sampling. Pengambilan sampel sesuai dengan perlakuan yang diberikan. Perlakuan yang diberikan yaitu dosis pupuk hayati, yang terdiri atas 6 taraf perlakuan yaitu:

$$
\begin{aligned}
& \text { B0 }=0 \mathrm{~g} \mathrm{liter}^{-1} \operatorname{tanaman}^{-1} \\
& \text { B1 }=0.5 \mathrm{~g} \mathrm{liter}^{-1} \operatorname{tanaman}^{-1} \\
& \text { B2 }=1 \mathrm{~g} \mathrm{liter}^{-1} \operatorname{tanaman}^{-1} \\
& \text { B3 }=5 \mathrm{~g} \text { liter }^{-1} \operatorname{tanaman}^{-1} \\
& \text { B4 }=10 \mathrm{~g} \mathrm{liter}^{-1} \operatorname{tanaman}^{-1} \\
& \text { B5 }=15 \mathrm{~g} \mathrm{liter}^{-1} \operatorname{tanaman}^{-1}
\end{aligned}
$$

\section{HASIL DAN PEMBAHASAN}

Berdasarkan hasil pengamatan di lapangan diperoleh data pendukung $\mathrm{pH}$, suhu dan kelembaban yang dilakukan setiap pengambilan sampel dilapangan (Tabel 1). Hasil pengamatan data pendukung $\mathrm{pH}$, suhu dan kelembaban diperoleh hasil yang tidak jauh berbeda pada setiap pengamatan di lapangan. Pengamatan yang dilakukan dengan pengambilan 3 titik yang berbeda dari setiap pengamatan kemudian dirata-ratakan, diperoleh hasil pengamatan $\mathrm{pH}$ berkisar antara 6.4-6.8, suhu berkisar antara 27-34 ${ }^{\circ} \mathrm{C}$ dan kelembaban berkisar antara $13-25 \%$.

Tabel 1. Pengamatan hasil data pendukung $\mathrm{pH}$, suhu dan kelembaban

\begin{tabular}{cccc}
\hline \multirow{2}{*}{ Pengamatan ke- } & \multicolumn{3}{c}{ Pengamatan } \\
\cline { 2 - 4 } & $\mathrm{pH}$ & Suhu $\left({ }^{\circ} \mathrm{C}\right)$ & Kelembaban $(\%)$ \\
\hline 1 & 6.8 & 30 & 25 \\
2 & 6.6 & 27 & 15 \\
3 & 6.4 & 34 & 13 \\
\hline
\end{tabular}


Isolasi cendawan dan bakteri yang diperoleh dari penelitian ini berasal dari sampel tanah yang diambil dari tanah lahan bekas tambang timah yang ditanami tanaman lada. Sampel tanah yang diambil yaitu sebanyak 6 sampel tanah setiap perlakuan. Seluruh sampel tanah kemudian ditumbuhkan pada media PDA untuk cendawan, media NA untuk bakteri dan media pikovskaya untuk pengujian mikrob pelarut fosfat baik untuk bakteri maupun cendawan, sehingga diperoleh sebanyak 54 cawan. Setiap cawan akan tumbuh isolat yang mampu tumbuh pada media tersebut. Menurut Dewi (2008) isolasi merupakan pengambilan atau memindahkan mikrob dari lingkungannya di alam dan menumbuhkannya sebagai biakan murni dalam medium buatan. Pemurnian isolat bertujuan untuk mendapatkan biakan murni. Lay (1994) menyatakan bahwa biakan murni merupakan biakan yang hanya mengandung satu jenis isolat.

Hasil identifikasi cendawan diperoleh 6 genus cendawan yaitu Aspergilus spp., Bipolaris spp., Fusarium spp., Gliocladium spp., Penicillium spp., dan Trichoderma spp. Keenam genus cendawan ini sebagian besar bersifat patogen (Tabel 2). Menurut Gandjar et al. (2000) Aspergillus spp. umumnya cendawan yang bersporulasi dengan lebat dan bersifat patogen. Bipolaris spp. merupakan cendawan yang bersifat patogen yang menyebabkan penyakit bercak pada tanaman (Shurfleff, 1980). Cendawan Gliocladium spp. merupakan cendawan tanah yang hidupnya bersifat saprofit (Collins, 1976). Menurut Semangun (1996) cendawan Penicillium spp. umumnya bersifat saprofit dapat merusak hasil-hasil pertanian. Cendawan Trichoderma spp. merupakan cendawan yang secara alami menyerang cendawan patogen dan bersifat menguntungkan bagi tanaman (Purwantisari, 2009).

Tabel 2. Enam genus cendawan dari masing-masing perlakuan

\begin{tabular}{|c|c|c|c|}
\hline \multirow[t]{2}{*}{ Perlakuan } & \multicolumn{3}{|c|}{ Pengamatan ke- } \\
\hline & 0 & 1 & 2 \\
\hline \multirow[t]{2}{*}{ B0 } & Aspergillus sp. & Aspergillus sp. & - \\
\hline & & Penicillium pp. & - \\
\hline \multirow[t]{3}{*}{$\mathrm{B} 1$} & Aspergillus sp. & Fusarium sp. & - \\
\hline & Penicillium sp. & Penicillium sp. & - \\
\hline & & Trichoderma sp. & - \\
\hline B2 & Penicillium sp. & $\begin{array}{l}\text { Aspergillus sp. } \\
\text { Fusarium sp. } \\
\text { Penicillium sp. }\end{array}$ & Penicillium sp. \\
\hline \multirow[t]{3}{*}{ B3 } & - & Aspergillus sp. & Penicillium sp. \\
\hline & - & Fusarium sp. & Trichoderma sp. \\
\hline & - & Penicillium sp. & \\
\hline \multirow[t]{3}{*}{ B4 } & - & Aspergillus sp. & - \\
\hline & - & Bipolaris sp. & - \\
\hline & - & Trichoderma sp. & - \\
\hline B5 & Penicillium sp. & $\begin{array}{l}\text { Fusarium sp. } \\
\text { Penicillium sp. }\end{array}$ & $\begin{array}{l}\text { Gliocladium sp. } \\
\text { Penicillium sp. }\end{array}$ \\
\hline
\end{tabular}

Hasil pengamatan genus cendawan tidak berpengaruh terhadap perlakuan B2 dan B5 karena perlakuan B2 dan B5 pada pengamatan ke-3 masih terdapat cendawan patogen yang mendominasi. Sedangkan perlakuan B1, B3 dan B4 pada pengamatan ke-3 tidak terdapat cendawan patogen yang mendominasi. Hal ini mengindikasikan pupuk hayati yang diaplikasikan mengandung bakteri, bakteri mampu menghambat pertumbuhan cendawan patogen. Menurut Mihardjo dan Majid (2008), mekanisme penghambatan patogen oleh mikrobia antagonis umumnya disebabkan karena proses antibiosis, kompetisi nutrisi dan parasitisme. Kemampuan menghambat pertumbuhan cendawan patogen tersebut adalah karena adanya zat antibiosis yang dihasilkan oleh bakteri dan secara difusi melalui medium dapat menghambat pertumbuhan cendawan patogen. Mikrob yang menghasilkan mekanisme antibiosis dianggap lebih tepat digunakan untuk menekan perkembangan patogen (Wibowo, 2001).

Hasil pewarnaan gram diperoleh adanya gram negatif dan gram positif. Bakteri gram positif terlihat berwarna ungu karena asam-asam ribonukleat pada sitoplasma sel-sel gram positif membentuk ikatan yang lebih kuat dengan kompleks ungu kristal violet sehingga ikatan kimiawi tersebut tidak mudah dipecahkan oleh pemucat warna (Hadioetomo, 1993). Reaksi tersebut didasarkan atas perbedaan komposisi kimiawi dinding sel. Sel gram positif mempunyai dinding dengan lapisan peptidoglikan yang tebal (Sunatmo, 2007). Bakteri gram negatif terlihat berwarna merah muda. Bakteri gram negatif mengandung lipid dan lemak dalam persentase yang lebih tinggi daripada bakteri gram positif). Selain itu bakteri gram negatif juga memiliki peptidoglikan yang lebih tipis daripada bakteri gram positif (Sunatmo, 2007). Bentuk sel bakteri secara mikroskopis ada coccus, bacillus, coccobacillus, diplobacillus, diplococcus dan tetracoccus (Tabel 3). Keseluruhan bentuk sel bakteri yang didapatkan dari 90 isolat bakteri adalah berbentuk bacillus (batang). Bentuk-bentuk sel merupakan cara untuk melihat karakteristik dari suatu bakteri yaitu berbentuk bulat, batang dan koma (James et al., 2008). Pewarnaan gram bakteri yang diperoleh dominan adalah gram negatif yaitu dari 90 isolat terdapat 80 isolat bakteri yang termasuk gram negatif. Hal ini sejalan dengan hasil penelitian Suryanto dan Munir (2006) bahwa lebih banyak didapat bakteri gram negatif dengan bentuk sel basil dan kokus.

Pupuk hayati yang digunakan pada penelitian ini mengandung mikrob penambat $\mathrm{N}$, pelarut $\mathrm{P}$ dan penghasil fitohormon. Adapun mikrob yang terkandung pada pupuk hayati yang digunakan terdiri dari beberapa bakteri antara lain Azotobacter vinelandii (penambat $\mathrm{N}$ non simbiotik dan pelarur $\mathrm{P}$ tanah), Azospirilum sp (penambat N2 non simbiotik dan penghasil fitohormon, Bacillus cereus (pelarut posfat tanah, penghasil senyawa anti patogen) Bhradyrhizobium sp (penambat $\mathrm{N}$ simbiotik), serta Methylobacterium sp (penghasil fitohormon). Keberadaan bakteri penambat $\mathrm{N}$ bebas pada daerah perakaran tanaman menguntungkan karena dapat membantu mencukupi kebutuhan $\mathrm{N}$ tanaman tersebut. Hubungan antara bakteri penambat $\mathrm{N}$ seperti ini diduga juga terjadi pada perakaran tanaman lada (Piper nigrum L.). 
Tabel 3. Pengamatan mikroskopis isolat bakteri

\begin{tabular}{|c|c|c|c|c|c|c|c|c|c|}
\hline & \multicolumn{3}{|c|}{ Sebelum } & \multicolumn{3}{|c|}{ 1 Bulan Setelah Aplikasi } & \multicolumn{3}{|c|}{2 Bulan Setelah Aplikasi } \\
\hline & Bentuk Sel & Gram & Jumlah Isolat & Bentuk Sel & Gram & Jumlah Isolat & Bentuk Sel & Gram & Jumlah Isolat \\
\hline \multirow[t]{4}{*}{ B0 } & & & & Bacillus & - & 1 & Bacillus & - & 3 \\
\hline & & & & Coccus & - & 1 & & & \\
\hline & & & & Tetracoccus & + & 1 & & & \\
\hline & & & & Tetracoccus & - & 1 & & & \\
\hline \multirow[t]{4}{*}{ B1 } & Bacillus & - & 1 & Bacillus & - & 2 & Bacillus & - & 3 \\
\hline & & & & Coccus & + & 1 & & & \\
\hline & & & & Coccus & - & 2 & & & \\
\hline & & & & Diplococcus & - & 3 & & & \\
\hline \multirow[t]{2}{*}{ B2 } & Coccus & - & 1 & Bacillus & - & 6 & Bacillus & - & 1 \\
\hline & Bacillus & - & 6 & Coccobacillus & + & 1 & Bacillus & + & 1 \\
\hline \multirow[t]{6}{*}{ B3 } & & & & Bacillus & - & 3 & Bacillus & - & 10 \\
\hline & & & & Coccus & - & 1 & Bacillus & + & 1 \\
\hline & & & & Coccobacillus & - & 1 & Coccus & - & 2 \\
\hline & & & & Diplobacillus & - & 1 & Coccobacillus & - & 1 \\
\hline & & & & Diplococcus & - & 1 & & & \\
\hline & & & & Tetracoccus & + & 1 & & & \\
\hline \multirow[t]{3}{*}{ B4 } & & & & Bacillus & - & 6 & Bacillus & - & 6 \\
\hline & & & & Coccus & - & 1 & Diplobacillus & - & 3 \\
\hline & & & & Coccobacillus & - & 2 & & & \\
\hline \multirow[t]{5}{*}{ B5 } & & & & Bacillus & - & 1 & Bacillus & - & 6 \\
\hline & & & & Coccus & - & 2 & Bacillus & + & 1 \\
\hline & & & & Coccus & + & 1 & Coccus & - & 1 \\
\hline & & & & Coccobacillus & - & 1 & Diplobacillus & + & 1 \\
\hline & & & & Diplococcus & + & 1 & & & \\
\hline
\end{tabular}

Hasil perhitungan kelimpahan mikrob pada total populasi bakteri dan cendawan bahwa semua perlakuan menunjukkan hasil yang tidak berpengaruh terhadap kontrol, dari grafik dapat dilihat pola setiap perlakuan tidak konsisten. Perbandingan antara total populasi bakteri dengan cendawan, bakteri lebih baik dibandingkan cendawan. Hal ini disebabkan kandungan dari pupuk hayati yang digunakan mengandung bakteri, sehingga cendawan yang tumbuh banyak berasal dari mikrob pribumi (native) seperti yang dijelaskan oleh Kloepper dan Schroth (1978) bahwa rizobacteria merupakan mikrob kompetitor yang paling efisien yang mampu menggeser kedudukan mikrob pribumi (native) di lingkungan rizosfer sampai pada masa pertengahan umur tanaman. Perhitungan kelimpahan total populasi cendawan yang baik pada perlakuan B4 (10 g liter${ }^{1}$ tanaman $^{-1}$ ) hal ini di duga bahwa kelimpahan cendawan tinggi karena rendahnya kelimpahan bakteri yang tersedia, sehingga tidak mampu menekan cendawan (Gambar 1). Sedangkan kelimpahan total populasi bakteri yang baik pada perlakuan B3 (5 g liter $\left.\mathrm{g}^{-1} \operatorname{tanaman}^{-1}\right)$ hal ini di duga bahwa perlakuan B3 (5 g liter $\left.{ }^{-1} \operatorname{tanaman}^{-1}\right)$ memiliki kemampuan aktivitas mikrob yang bisa menghambat pertumbuhan cendawan patogen. Aktivitas mikrob tanah berbanding lurus dengan jumlah total mikrob di dalam tanah, jika total mikrob tinggi maka aktivitas mikrob juga semakin tinggi (Wicaksono, 2015).

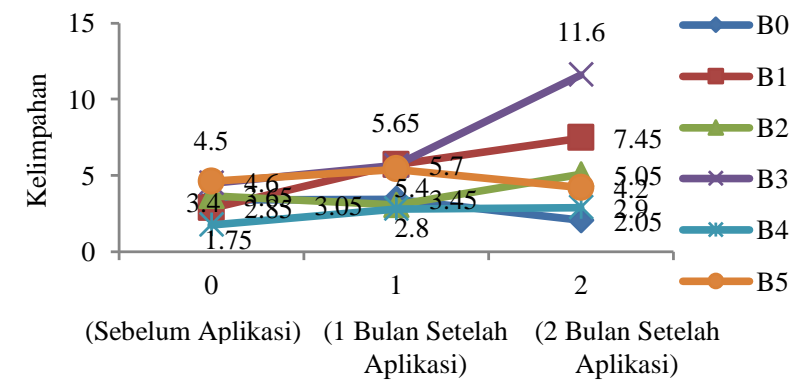

Gambar 1. Kelimpahan bakteri sebelum dan setelah aplikasi pupuk hayati
Aktivitas mikrob tanah merupakan suatu proses yang terjadi karena adanya kehidupan mikrob yang melakukan aktivitas hidup dalam suatu massa tanah. Aktivitas mikrob tanah dapat dimonitor dari karakter sifat fisika-kimia tanah meliputi: pH (6.0-8.0), temperatur $\left(0-90{ }^{\circ} \mathrm{C}\right)$, kelembaban, berat volume dan berat kering tanah), laju respirasi tanah, aktivitas enzim dehidrogenase tanah dan total populasi bakteri tanah (Kapli, 2015). Hasil pengamatan menunjukkan bahwa $\mathrm{pH}$ tanah pada lahan bekas tambang yang ditanami tanaman lada berkisar antara 6.4-6.8, sehingga pertumbuhan mikrob didalam tanah masih bisa hidup (Suwarto, 2013). Reaksi tanah (pH) mempengaruhi perkembangan mikrob tanah yang hidup di dalamnya. Adapun mikrob yang banyak hidup pada $\mathrm{pH}$ ini adalah bakteri dan fungi. Menurut Lay (1994) pada umumnya bakteri dapat tumbuh dengan baik pada $\mathrm{pH}$ sekitar 7 (netral) meskipun dapat tumbuh pada kisaran $\mathrm{pH}$ 5-8 sedangkan fungi dapat hidup pada kisaran $\mathrm{pH}$ yang luas. Hasibuan dan Ritonga (1981) juga menyatakan $\mathrm{pH}$ tanah mempengaruhi perkembangan mikrob tanah pada kondisi tanah berbeda, apalagi di air (Setiawati et al., 2016). Suhu yang diperoleh berkisar antara $27-34{ }^{\circ} \mathrm{C}$, pertumbuhan mikrob masih bisa terjadi.

Pengamatan morfologi yang dilakukan terhadap isolat bakteri secara makroskopis meliputi, bentuk koloni, bentuk tepian koloni, warna koloni, dan pengamatan secara mikroskopis pewarnaan gram serta bentuk sel dari bakteri. Hasil pengamatan terhadap bentuk morfologi koloni bakteri maka diperoleh isolat berbentuk bulat beraturan, bulat tidak beraturan, irregular, berfilament, hampir semua isolat memiliki bentuk tepian koloni yang rata. Menurut Hidayat et al. (2006) bahwa bentuk koloni dari suatu bakteri dipengaruhi oleh umur dan syarat pertumbuhan tertentu. Variasi bentuk bakteri yang terjadi juga dipengaruhi oleh lingkungan (faktor biotik dan abiotik), faktor makanan (medium tumbuh) dan suhu (minimum, optimum dan maksimum) (Ilyas, 2001). Warna koloni sebagian besar isolat berwarna putih. Warna koloni yang tampak berbedabeda menunjukkan adanya perbedaan pigmen. 
Pemberian dosis pupuk hayati berpengaruh terhadap BPF dan CPF pada setiap perlakuan (Gambar 2). Populasi bakteri pelarut fosfat tertinggi pada perlakuan B3 (5 g liter${ }^{1}$ tanaman $^{-1}$ ), sedangkan populasi cendawan pelarut fosfat tertinggi pada perlakuan B2 (1 g liter $\left.{ }^{-1} \operatorname{tanaman}^{-1}\right)$. Pembentukan zona bening oleh isolat BPF dan CPF mengindikasikan kemampuannya dalam melarutkan fosfat. Sumber utama fosfor tanah dapat berasal dari pelapukan batuan (proses mineralisasi). Pada tanah masam, fosfor akan bersenyawa dengan aluminium membentuk Al-P, sedangkan pada tanah alkali, fosfor akan bersenyawa dengan kalsium membentuk Ca-P yang sukar larut sehingga tidak tersedia untuk tanaman (Ilham et al., 2014). Pengikatan-pengikatan fosfat tersebut menyebabkan pupuk fosfat yang diberikan tidak efisien sehingga perlu diberikan dalam takaran tinggi. Namun, tanaman hanya dapat menyerap sekitar $15-20 \%$ fosfat yang berasal dari pemupukan. Adapun sisanya akan terjerap di antara koloid tanah dan tinggal sebagai residu di dalam tanah. Hal ini akan menyebabkan defisiensi fosfat bagi pertumbuhan tanaman (Simanungkalit dan Suriadikarta, 2006).
A

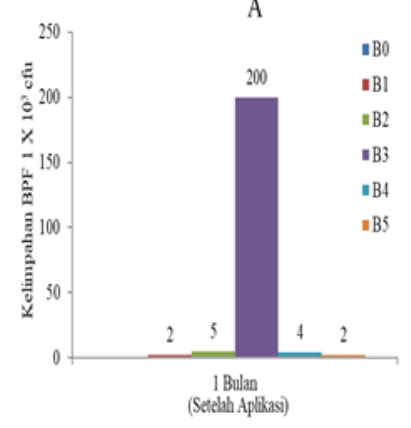

B

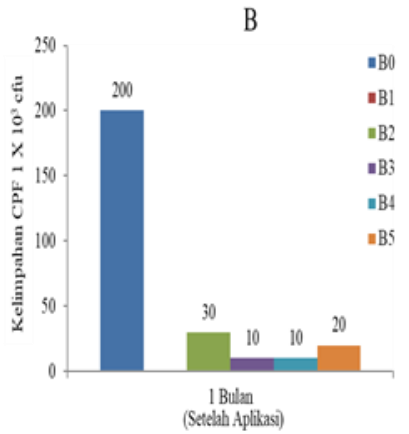

Gambar 2. Kelimpahan mikrob pelarut fosfat; (A) bakteri pelarut fosfat (BPF); (B) cendawan pelarut fosfat (CPF).

Berdasarkan hasil pengamatan uji penambat $\mathrm{N}$ diperoleh bahwa perlakuan B4 (10 g liter ${ }^{-1}$ tanaman $\left.^{-1}\right)$ memberikan pengaruh yang lebih baik dari perlakuan lainnya, hal ini sejalan dengan penelitian pertumbuhan yang diperoleh kandungan klorofilnya tinggi pada perlakuan B4 (10 g liter-1 $\operatorname{tanaman}^{-1}$ ). Diduga dari pengamatan yang diperoleh bahwa bakteri penambat $\mathrm{N}$ ini termasuk golongan genus Azotobacter. Hal ini sesuai dengan pendapat Brock et al. (1994) bahwa Genus Azotobacter dicirikan dengan sel berbentuk batang, gram negatif, bersifat aerobik obligat dan mempunyai ukuran sel yang lebih panjang dari prokariot lainnya dengan diameter sel 2-4 $\mu \mathrm{m}$ atau lebih. Beberapa strain motil dengan flagelperitrikha. Pada media mengandung karbohidrat, bakteri ini membentuk kapsul yang berfungsi melindunginya dari lingkungan luar. Penelitian ini menunjukkan bahwa tidak ada bakteri genus Azospirilum yang ditemukan, karena bakteri Azospirilum tidak tumbuh pada media selektif khusus Azospirilum. Genus bakteri Azospirilum mempunyai ciri berupa sel yang berbentuk setengah spiral yang padat dan bergetar dengan sebuah flagel polar sehingga bergerak secara berputar (Haran dan Ansori, 1992).

Hasil kelimpahan mikrob yang dilakukan sebanyak 3 kali pengamatan yaitu 0 (sebelum aplikasi pupuk hayati), 1 bulan (setelah aplikasi pupuk hayati) dan 2 bulan (setelah aplikasi pupuk hayati) diperoleh hasil terlihat dinamika mikrob yang tumbuh pada setiap pengamatan. Pengamatan 1 bulan (setelah aplikasi pupuk hayati) merupakan pengamatan yang lebih baik dari pengamatan 2 bulan (setelah aplikasi pupuk hayati) baik bakteri maupun cendawan mengalami peningkatan yang cepat dari pengamatan 0 (sebelum aplikasi pupuk hayati). Hal ini mengindikasikan bahwa variabel waktu sangat menentukan untuk mikrob yang dilepaskan untuk beradaptasi dengan lingkungan.

\section{SIMPULAN}

Pemberian dosis pupuk hayati tidak berpengaruh terhadap dinamika kelimpahan mikrob tanah di lahan bekas tambang timah yang ditanami tanaman lada (Piper nigrum L.)

Pemberian dosis pupuk hayati perlakuan B3 (5 g liter $^{-1} \operatorname{tanaman}^{-1}$ ) memberikan pertumbuhan optimal mikrob di lahan bekas tambang timah yang ditanami tanaman lada (Piper nigrum L.)

\section{DAFTAR PUSTAKA}

Adesemoye, A.O., M. Obini and E.O. Ugoji. 2008. Comparison of plant growth promotion with Pseudomonas aeruginosa and Bacillus subtilis in three vegetables. Brazilian Journal of Microbiology, 39:423-426.

Brock, T.D., M.T. Madigan and J.M. Martinko. 1994. Biology of Microorganism, seventh edition. Prentice Hall, New Jersey.

Collins, C.I.I. dan P.M. Lyne. 1976. Microbiological Methods Foundation. Butterworths, London.

Dewi, I.M. 2008. Isolasi Bakteri dan Uji Aktifitas Kitinase Termofilik Kasar dari Sumber Air Panas Tinggi Raja, Simalungun, Sumatera Utara [Tesis]. Sekolah Pascasarjana Universitas Sumatera Utara, Medan.

Fadiluddin, M. 2009. Efektivitas Formula Pupuk Hayati dalam Memacu Serapan Hara, Produksi, dan Kualitas Hasil Jagung dan Padi Gogo [Tesis]. Sekolah Pascasarjana Institut Pertanian Bogor, Bogor.

Gentili, F., and A. Jumpponen. (2005). Handbook of Microbial Fertilizers. Rai MK, editor. The Hawort Press, Inc: New York.

Hadioetomo, R.S. 1993. Mikrobiologi Dasar dalam Praktek Teknik dan Prosedur Dasar Laboratorium. Penerbit Gramedia, Jakarta.

Haran, S. dan N. Ansori (Eds). 1992. Bioteknologi Pertanian Bogor. Pusat Antar Universitas. Bioteknologi, Institut Pertanian Bogor, Bogor.

Hasibuan, B.E. dan M.D. Ritonga. 1981. Ilmu Tanah Umum. Fakultas Pertanian, USU, Medan.

Hidayat, N., M.C. Padaga dan S. Suhartini. 2006. Mikrobiologi Industri. Penerbit ANDI, Yogyakarta. 
Ilham, I.B.G. Darmayasa, I.G.M.O. Nurjaya dan R. Kawuri. 2014. Isolasi dan Identifikasi Bakteri Pelarut Fosfat Potensial pada Tanah Konvensional dan Tanah Organik. Jurnal Simbiosis, 2(1):173-183.

Ilyas, S. 2001. Mikrobiologi Dasar Diklat Kompilasi 28. Universitas Sumatera Utara Press, Medan.

Iqbal, A., M. Sajjad, A. Khan, F. Aqil and M. Singh. 2011. Microbial Appliations in Agriculture and the Environment. In Ahmad I., Ahmad F., Pichtel J. (eds) Microbes and Microbial Technology. Springer, New York.

James, J., C. Baker dan H. Swain. 2008. Prinsip-Prinsip Sains untuk Keperawatan. Erlangga, Jakarta.

Kapli, H. 2015. Kelimpahan dan Aktivitas Mikrob Tanah Pasca Aplikasi PGPR serta Peranannya pada Tanaman Jagung (Zea mays. L) [Tesis]. Institut Pertanian Bogor, Bogor.

Kloepper, J.W. and M.N. Schroth. 1978. Plant growth promotting rhizobacteria on radishes. In Angers, Editor. In Proceedings of the fourth International Conference on Plant Pathogenic bacteria. 1978 september 2; INRA,p 879-882. France

Lay, W.B. 1994. Analisis Mikrob di Laboratorium. PT Raja Grafindo Persada, Jakarta.

Mc. Mahon, M.E., A.M. Kofranek and V.E. Rubatzky. 2011. Hartmann's Plant Science Growth Development and Utilization of Cultified Plants 4th Edition. Pearson Education, inc. Upper Saddle River, New Jersey.

Mihardjo, Ashna dan A. Majid. 2008. Pengendalian Penyakit Layu pada Pisang dengan Bakteri Antagonis Pseudomomas flourescens dan Bacillus subtilis. Jurnal Pengendalian Hayati, 1(12):26-31.

Nasahi, H.C. 2010. Peran Mikrob dalam Pertanian Organik. Fakultas Pertanian, Universitas Padjadjaran, Bandung.

Nunik, S., S. Antonius dan R. Maman. 2011. Pengaruh Residu Pestisida Terhadap Pola Populasi Bakteri dan Fungi Tanah di Rumahkaca. Jurnal Teknologi Lingkungan, 12(1):43-53.

Prajnanta, F. 2004. Pemeliharaan Tanaman Budidaya Secara Intensif dan Kiat Sukses Beragribisnis. Penebar Swadaya Press, Bogor.

Purwantisari, S. 2009. Isolasi dan Identifikasi Cendawan Indigenous Rhizosfer Tanaman Kentang dari Lahan Pertanian Kentang Organik di Desa Pakis. Magelang. Jurnal BIOMA, 11(2):45.

Saraswati, R. dan Sumarno. 2008. Pemanfaatan Mikrob Penyubur Tanah. Iptek Tanaman Pangan, 3(1):4158.

Saraswati R. 2012. Teknologi pupuk hayati untuk efisiensi pemupukan dan keberlanjutan sistem produksi pertanian. Dalam: Wigena P, Nurida NL, Setyorini D, Husnain, Husen E, Suryani E, editors. Seminar Nasional Pemupukan dan Pemulihan Lahan Terdegradasi; 2012 Jun 29-30. Balai Besar
Penelitian dan Pengembangan Sumberdaya Lahan Pertanian. hlm. 727-738. Bogor.

Semangun, H. 1996. Ilmu Penyakit Tumbuhan. Gadjah Mada University Press, Yogyakarta.

Setiawati, M., D. Jusadi and R. Diana. 2016. Kecernaan Pakan dan Pertumbuhan Ikan Patin Pangasius hypopthalmus yang diberi Tepung dan Ekstrak Daun Kayu Manis Cinnamomum burmanni. Jurnal Ilmu Pertanian Indonesia (JIPI), 21(3):219-223.

Shurtleff, M.C. 1980. Compendium of Corn Disease. Second Ed. The American Phytopathological Society, Pp. 105. United State

Simanungkalit, R.D.M., E. Husein dan Saraswati. 2006. Baku Mutu Pupuk Hayati dan Sistem Pengawasannya. Balai Besar Penelitian dan Pengembangan Sumberdaya Lahan Pertanian, Bogor.

Simanungkalit, R.D.M. and D.A. Suriadikarta. 2006. Pupuk Organik dan Pupuk Hayati. Balai Besar Penelitian dan Pengembangan Sumber Daya Lahan Pertanian, Bogor.

Sofatin, S., B.N. Fitria dan Y. Machfud. 2016. Pengaruh Kombinasi Pupuk NPK dan Pupuk Hayati terhadap Populasi Total Mikrob Tanah dan Hasil Jagung Manis (Zea mays L. saccharata) pada Inceptisols Jatinangor. Jurnal Soilrens, 14(2):3337

Sudrajat, D., N. Mulyana dan A. Adhari. 2014. Seleksi Mikrob Rizosfer Lokal untuk Bioaktif pada Inokulan Berbasis Kompos Iradiasi. Jurnal Ilmiah Aplikasi Isotop dan Radiasi, 10(1):23-34.

Sujitno, S. 2007. Sejarah Timah di Pulau Bangka. PT. Timah tbk, Pangkalpinang.

Sunatmo, T.I. 2007. Eksperimen Mikrobiologi dalam Laboratorium. Ardy Agency, Bogor.

Suryanto, D. dan E. Munir. 2006. Potensi Pemanfaatan Isolat Bakteri Kitinolitik Lokal untuk Pengendali Hayati Jamur. In Prosiding Seminar Hasil-Hasil Penelitian USU, Pp. 15-25. Medan

Suwahyono, U. 2011. Petunjuk Praktis Penggunaan Pupuk Organik Secara Efektif dan Efisien. Penebar Swadaya, Jakarta.

Suwarto. 2013. Lada Produksi 2 ton/ha. Penebar Swadaya, Jakarta.

Vessey, J.K. 2003. Plant Growth Promoting Rhizobakteria as Biofertilizers. Plant and Soil, 255:571-586.

Watanabe, I. 1979. Biological Nitrogen Fixation in Rice Soils. In Soils and Rice. IRRI. Pp. 465-478. Los Banos, Philippines.

Wibowo, A. 2001. Suppression of Sheath Blight Of Rice With Antagonistic Bacteria. Perlindungan Tanaman Indonesia, 7(2):21-25.

Wicaksono, T. 2015. Kajian Aktivitas Mikrob Tanah Pada Beberapa Cara Penggunaan Lahan Di Desa Pal 
IX Kecamatan Sungai Kakap Kabupaten Kubu Raya. Universitas Tanjungpura, Pontianak. 